\title{
A synopsis of Chlamydocardia (Acanthaceae) including Linocalix
}

\author{
lain Darbyshire ${ }^{1}$ (D) \& Rafaël Govaerts ${ }^{1}$
}

Summary. Linocalix Lindau, one of the few remaining unplaced genera for the World Checklist of Selected Plant Families database, is found to be a synonym of Chlamydocardia Lindau (Acanthaceae). An extant type at the BR herbarium of Linocalix albus Lindau is referable to Chlamydocardia subrhomboidea Lindau. A synopsis of the two species of Chlamydocardia, C. buettneri Lindau (including C. lanciformis Lindau) and C. subrhomboidea is provided, together with an identification key and a discussion of their status. Neotypes are selected for C. buettneri and C. subrhomboidea, and C. lanciformis and Linocalix albus are lectotypified.

Key Words. African plants, synonymy, taxonomy, type specimen, World Checklist of Selected Plant Families.

\section{Introduction}

Lindau (1913) described the monotypic genus Linocalix from Bare in Cameroon as part of his ongoing studies on the African Acanthaceae, placing it near the genus Gatesia A. Gray (= Yeatesia Small fide Scotland \& Vollesen 2000). Linocalix has since largely disappeared from the taxonomic literature, not having been mentioned in the relevant publications on West African Acanthaceae (most notably Heine 1963, 1966) nor in checklists of the tropical African flora (Lebrun \& Stork 1997; Klopper et al. 2006) or the vascular plants of Cameroon (Onana 2011). In their classification of Acanthaceae, Scotland \& Vollesen (2000) listed Linocalix (as Linocalyx) as a synonym of Justicia L. but without further elaboration or justification. With a treatment of the Acanthaceae for the Flore du Cameroun series yet to be produced, the status of Linocalix has remained unconfirmed. Thus Linocalix was one of the last genera of vascular plants to remain unresolved in the World Checklist of Selected Plant Families database (R. Govaerts, pers. data) and on The Plant List (2013). The specimen of the single species, L. albus Lindau (Ledermann 6140) at Berlin is believed to have been destroyed by the bombing of the Berlin herbarium during World War II. Fortunately, a duplicate of this collection is held at the BR herbarium and is available via the JSTOR Global Plants website (under Linocalyx albus; JSTOR 2016). Whilst depauperate, this specimen does include a flowering spike with one young corolla visible, which is a close match for the rare species Chlamydocardia subrhomboidea Lindau. This placement is confirmed by Lindau's description of L. albus in the protologue, which is a good match for C. subrhomboidea. Linocalix is therefore synonymised within Chlamydocardia here.

Chlamydocardia was placed in subtribe Justiciinae of tribe Ruellieae of subfamily Acanthoideae in the classification of the Acanthaceae by Scotland \& Vollesen (2000).
More recent molecular evidence places the genus as the basal-most clade of the "Tetramerium lineage" (Daniel et al. 2008), one of the four major lineages in the tribe Justiceae sensu McDade et al. (2000). Chlamydocardia is recognised by having the combination of (1) a small (c. $9-12 \mathrm{~mm}$ long), corolla with a narrowly cylindrical tube much longer than the reflexed limb (the lower lip fully divided into three lobes, the upper lip comprising two almost completely fused lobes); (2) anthers with unequal-sized thecae but these held at \pm the same height (i.e. not offset) and lacking appendages; and (3) broadly prolate to subglobose, 6-zonocolporate pollen with a mesocolpium of numerous verruculae often arranged in \pm well defined longitudinal lines (Daniel et al. 2008; Darbyshire 2010; Fig. 1). This pollen type has been proposed as a synapomorphy for the genus (Daniel et al. 2008; see also Scotland \& Vollesen 2000: fig. 39 A \& B). Lindau's description of the pollen of Linocalix albus is a close match for this unique pollen type Two species of Chlamydocardia are currently recognised; these are summarised in the taxonomic account below and an identification key is presented.

\section{Taxonomic account}

Chlamydocardia Lindau (1894: 39); Clarke (1900: 234); Heine (1963: 423; 1966: 184); Darbyshire (2010: 648). Type species: Chlamydocardia buettneri Lindau.

Linocalix Lindau (1913: 39), synon. nov. Type species: Linocalix albus Lindau.

Genus nov. sensu Vollesen \& Darbyshire (2004: 231).

Bracts variously obovate, linear-oblanceolate or spathulateobcordiform, widest in the distal half, $0.7-7 \mathrm{~mm}$ wide.

..C. buettneri

\footnotetext{
Accepted for publication 14 August 2017. Published online 7 September 2017

1 Herbarium, Royal Botanic Gardens, Kew, Richmond, Surrey, TW9 3AB, UK. e-mail: i.darbyshire@kew.org
} 

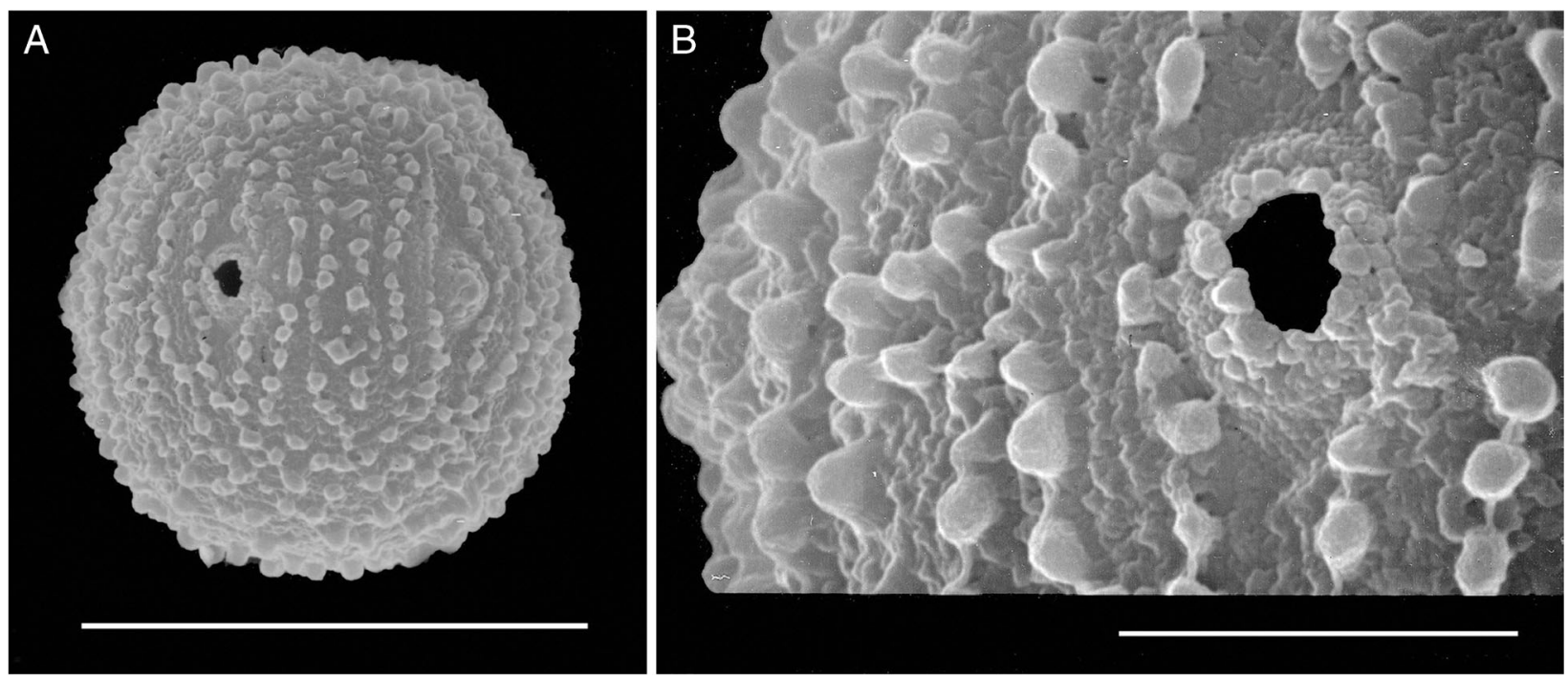

Fig. 1. SEM images of the pollen of Chlamydocardia buettneri. A whole grain, equatorial view (scale bar $=50 \mu \mathrm{m}$ ); $\mathrm{B}$ detail of aperture and sculpturing (scale bar $=10 \mu \mathrm{m})$. Images from Brenan 9317 ex Cameroon.

Bracts ovate, elliptic or subrhombic, widest in the proximal half or at the midpoint, $6-9.5 \mathrm{~mm}$ wide. C. subrhomboidea

Chlamydocardia buettneri Lindau (1894: 39); Clarke (1900: 234); Heine (1963: 423; 1966: 185, pl. 38: 1 - 9); Vollesen (1998: 2); Vollesen \& Darbyshire (2004: 224); Hawthorne \& Jongkind (2006: 438, 446, 447); Sosef (2006: 37); Darbyshire (2010: 650, fig. 83); Onana (2011: 30). Types: Gabon, Sibange Farm, fl. \& fr. Sept. 1884, Büttner 469 (B† holotype); Gabon, forêt de Mondah, N of Libreville, fl. 13 Aug. 1992, Dibata 1054 (K! neotype, selected here; MO, WAG isoneotypes). Fig. 2. Chlamydocardia lanciformis Lindau (1911: 300). Types: D.R. Congo, Beni, Muera, fl. \& fr. Jan. 1908, Mildbraed 2225 (B† syntype); pl. 32 G - J in Wiss. Ergebn. Deut. Zentr. Afr. Exped., Bot. 2, 1911 (lectotype, selected here).

DISTRIBUTION. Widespread in the wet GuineoCongolian forests of West and Central Africa: Ivory Coast, Nigeria, Cameroon, Equatorial Guinea, Gabon, Congo (-Brazzaville), D.R. Congo, Uganda.

CONSERVATION STATUS. This widespread species was assessed as of Least Concern (LC) by Darbyshire (2010). NOTES. Chlamydocardia buettneri is variable in terms of bract shape, ranging from broadly obovate (e.g. Casas 12100 from Bioko), to spathulate-obcordiform, i.e. with a narrowly cuneate or attenuate base and with two expanded rounded lobes towards the apex, usually also with a short acumen (e.g. Cable 841 from Cameroon, Keay in FHI 28278 from Nigeria; Fig. 2E), or linear-oblanceolate (e.g. Eilu 450 from Uganda, Fig. 2D). The lattermost form was previously separated as C. lanciformis but there are plants intermediate between this and the "spathulateobcordiform" bract form across its range, notably in
Uganda. What unites all these bract forms is that they are widest in the distal half, with a long-attenuate or -cuneate base and (except for linear-oblanceolate forms) with a short but marked acumen. Variants on the "spathulateobcordiform" bract shape are the most common and widespread form - these bracts are quite unlike anything seen elsewhere in African Acanthaceae.

The original specimen of Chlamydocardia buettneri is believed to have been destroyed by the bombing of the Berlin herbarium during World War II and no duplicates have so far been traced. Dibata 1054 is therefore chosen as a neotype as it is an informative specimen and the collecting locality is not too distant from the original type locality. Likewise, the original specimen of Chlamydocardia lanciformis is believed to have been lost in the same way; the illustration in the protologue is therefore selected as a lectotype here.

Chlamydocardia subrhomboidea Lindau (1895: 119); Clarke (1900: 235); Heine (1966: 185, in notes); Onana (2011: 30). Types: Cameroon, between Victoria [Limbe] and Bimbia, fl. 10 July 1894, Preuss 1309 (B† holotype); Cameroon, Moliki, fl. \& fr. Nov. 1938, Jacques-Félix 2534 (P 02894780! neotype, selected here; K!, P 02894779!, P 00536453! isoneotypes). Fig. 3.

Linocalix albus Lindau (1913: 408). Type: Cameroon, Bare, fl. 15 Nov. 1909, Ledermann 6140 (B十 isotype; BR 629 315 ! lectotype, chosen here), synon. nov.

Chlamydocardia buettneri sensu Heine (1963: 423) pro parte, non Lindau.

Genus nov. sensu Vollesen \& Darbyshire (2004: 231).

DISTRIBUTION. Cameroon, D.R. Congo.

CONSERVATION STATUS. Assessed as Endangered EN B2ab(iii) by Darbyshire \& Cheek (in Onana \& 


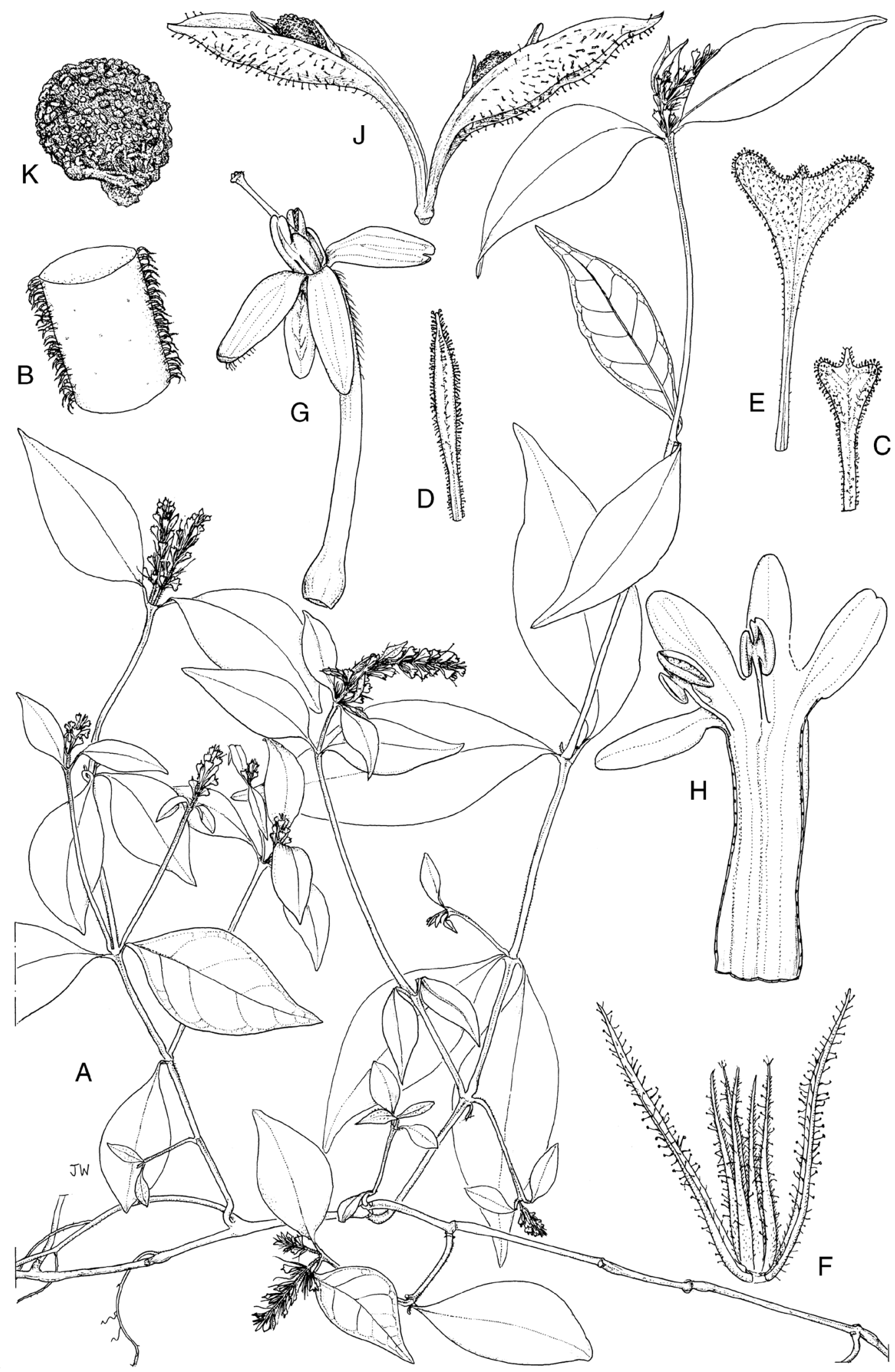

Fig. 2. Chlamydocardia buettneri. A habit; B detail of stem indumentum; C bract, outer surface; D bract, outer surface, narrow extreme; E bract, outer surface, "spathulate-obcordiform" form; F bracteoles and calyx; G corolla with stamens and pistil; $\mathrm{H}$ dissected corolla with stamens; J mature capsule with seeds; K mature seed. A - C \& H - K from G. Taylor 3312 ex Uganda; D from Eilu 450 ex Uganda; E from Cheek 7162 ex Cameroon; F \& G from Brenan 8455 ex Nigeria. Reproduced from F.T.E.A. Acanthaceae Part 2 (Beentje 2010: fig. 83), with permission of the Trustees of the Royal Botanic Gardens, Kew. DRAWN BY JULIET WILLIAMSON. 


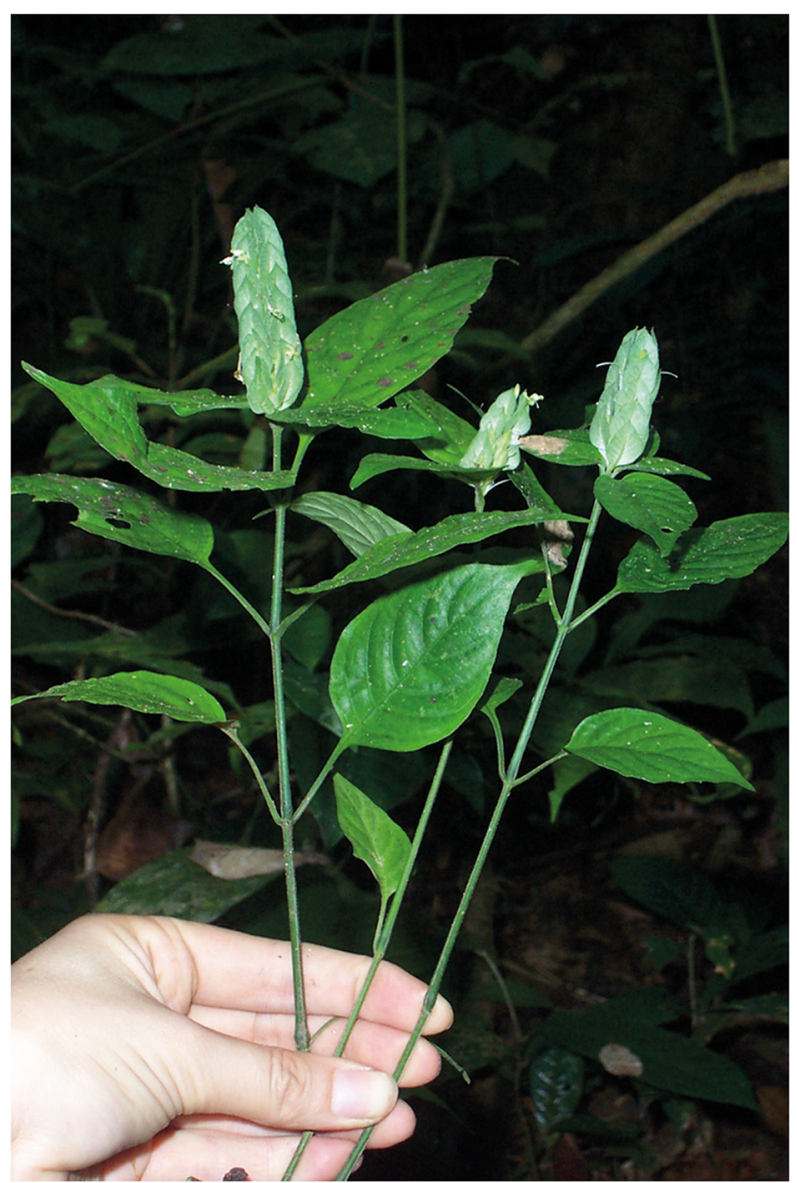

Fig. 3. Chlamydocardia subrhomboidea, collected as Osborne 299 ex Cameroon. PHOTO: J. OSBORNE.

Cheek 2011: 70) as it is known from only five locations and is threatened by conversion of its forest habitat to agricultural land in at least two of its known sites.

NOTES. Chlamydocardia subrhomboidea is usually easily separated from C. buettneri by its larger, ovate or at most elliptic bracts that lack an acumen, the apex being acute or at most shortly attenuate. These large bracts result in a more markedly strobilate flowering spike than in C. buettneri (see Fig. 3). In addition, C. subrhomboidea is typically a more robust plant than C. buettneri with larger leaves, but there is some overlap in these vegetative characters. A small number of specimens of C. buettneri from Cameroon (notably Brenan 9317 and Cable 1216, both K!) with particularly broad obovate bracts begin to approach those of C. subrhomboidea. It is therefore conceivable that C. subrhomboidea could be an extreme form of C. buettneri but this would be best investigated using molecular methods and it would be premature to reduce C. subrhomboidea to synonymy without such a study. Interestingly, Heine (1963) initially synonymised C. subrhomboidea within C. buettneri but later resurrected it as a clearly distinct species, after having studied specimens from Cameroon and D.R. Congo (Heine 1966).

The holotype of Chlamydocardia subrhomboidea is believed to have been destroyed by the bombing of the Berlin herbarium during World War II and no duplicates have so far been traced. A neotype is therefore selected here; one of the three $\mathrm{P}$ sheets of Jacques-Félix 2534 is chosen as this is an informative specimen, with both flowers and mature fruits, and the collection site is not too distant from the type locality; this specimen is also duplicated at $\mathrm{K}$.

\section{The identity of Chlamydocardia nuda}

Chlamydocardia nuda C. B. Clarke (1900: 235). Type: Gabon, Como R., 60 miles from Gaboon, fl. July 1896, Bates 494 (K! holotype; BM!, G-DC!, L!, $\mathrm{P}$ ! isotypes).

NOTES. This rare species, endemic to Gabon, was originally placed with some doubt in Chlamydocardia by Clarke (1900), but rejected from that genus by Lindau (1911). Heine (1966) subsequently transferred this species to Justicia L. with a new name J. tigrina Heine as the epithet nuda was already occupied in Justicia by J. nuda (Nees) O. Schwartz (Schwartz 1939: 259). Heine's J. tigrina remains the accepted name in current works (see e.g. Sosef 2006). However, this placement also appears to be in doubt and the status of this species is currently under investigation by the first author [I.D.] together with colleagues at Rancho Santa Ana Botanic Garden and the California Academy of Sciences. In any case, it certainly does not belong in Chlamydocardia, having a very different floral morphology to that genus: the corolla is markedly 2-lipped with only a shortly divided lower lip, the limb is approximately equal in length to the tube and the anther thecae are puberulous and markedly offset, each with a flattened basal "protoappendage" with small conical protrusions (see Heine 1966: pl. 38, 10 - 13).

\section{Acknowledgements}

Dr Robert Vogt of the Botanischer Garten und Botanisches Museum Berlin-Dahlem, Zentraleinrichtung der Freien Universität Berlin, is thanked for checking the Berlin herbarium collections for extant type material of Chlamydocardia. We thank Joanne Osborne $(\mathrm{K})$ for providing the photograph of the plant in situ and Carol Furness ( $\mathrm{K}$, retired) for the SEM images of the pollen of C. buettneri. Finally, we thank two anonymous reviewers for their helpful comments on an earlier version of the manuscript.

Open Access This article is distributed under the terms of the Creative Commons Attribution 4.0 International License (http://creativecommons.org/ 
licenses/by/4.0/), which permits unrestricted use, distribution, and reproduction in any medium, provided you give appropriate credit to the original author(s) and the source, provide a link to the Creative Commons license, and indicate if changes were made.

\section{References}

Beentje, H. J. (2010, ed.). Flora of Tropical East Africa. Acanthaceae (Part 2). Royal Botanic Gardens, Kew.

Clarke, C. B. (1900). Chlamydocardia. In: W. T. Thiselton-Dyer (ed.), Flora of Tropical Africa 5: 234 - 235. L. Reeve \& Co., London.

Daniel, T. F., McDade, L. A., Manktelow, M. \& Kiel, C. A. (2008). The "Tetramerium lineage" (Acanthaceae: Acanthoideae: Justicieae): delimitation and intralineage relationships based on $\mathrm{cp}$ and nrITS sequence data. Syst. Bot. 33: 416 - 436.

Darbyshire, I. (2010). Chlamydocardia, pp. 648 - 650 . In: H. J. Beentje (ed.), Flora of Tropical East Africa. Acanthaceae (Part 2). Royal Botanic Gardens, Kew.

Hawthorne, W. \& Jongkind, C. (2006). Woody Plants of Western African Forests. Royal Botanic Gardens, Kew.

Heine, H. (1963). Acanthaceae, pp. 391 - 432. In: F. N. Hepper (ed.), Flora of West Tropical Africa. Vol. 2. Second edition. Royal Botanic Gardens, Kew. (1966). Acanthacées, Flore du Gabon 13. Muséum National d'Histoire Naturelle, Paris.

JSTOR (2016). JSTOR Global Plants. Published on the Internet: https://plants.jstor.org/ (accessed 29th November 2016).

Klopper, R. R., Chatelain, C., Bänninger, V., Habashi, C., Steyn, H. M., de Wet, B. C., Arnold, T. H., Gautier, L., Smith, G. E. \& Spichiger, R. (2006). Checklist of the flowering plants of sub-Saharan Africa. An index of accepted names and synonyms. South African Botanical Diversity Network Report No. 42, SABONET, Pretoria.

Lebrun, J. P. \& Stork, A. L. (1997). Énumération des plantes à fleurs d'Afrique Tropicale. IV Gamopétales:
Ericaceae à Lamiaceae. Conservatoire et Jardin Botaniques de la ville de Genève.

Lindau, G. (1894). Acanthaceae africanae. II. Bot. Jahrb. Syst. 20: 1 - 76.

(1895). Acanthaceae africanae. III. Bot. Jahrb. Syst. 22: $112-127$.

(1911). Acanthaceae. In: J. Mildbraed (ed.), Wissenschaftliche Ergebnisse der Deutschen Zentral-Afrika Expedition 1907-1908, Band II. Botanik, pp. 291 - 310. Klinkhardt \& Biermann, Leipzig.

(1913). Acanthaceae africanae. IX. Bot. Jahrb. Syst. 49: 397 - 409.

McDade, L. A., Daniel, T. F., Masta, S. E. \& Riley, K. M. (2000). Phylogenetic relationships within the tribe Justicieae (Acanthaceae): evidence from molecular sequences, morphology, and cytology. Ann. Missouri Bot. Gard. 87: 435 - 458.

Onana, J. M. (2011). The Vascular Plants of Cameroon. A taxonomic checklist with IUCN assessments. Flore du Cameroon 39 "occasional volume", National Herbarium of Cameroon.

\& Cheek, M. (2011). Red Data Book of the Flowering Plants of Cameroon: IUCN global assessments. Royal Botanic Gardens, Kew.

The Plant List (2013). Version 1.1. Published on the Internet: http:/ /www.theplantlist.org/ (accessed 29th November 2016).

Schwartz, O. (1939). Flora der tropischen Arabien. Mitt. Inst. Allg. Bot. Hamburg 10: 1 - 393.

Scotland, R. W. \& Vollesen, K. (2000). Classification of Acanthaceae. Kew Bull. 55: 513 - 589.

Sosef, M. S. M. (2006). Acanthaceae. In: M. S. M. Sosef et al. (eds), Check-list des plantes vasculaires du Gabon / Checklist of Gabonese vascular plants. Scripta Botanica Belgica 35: 35 43. Jardin Botanique National du Belgique, Meise.

Vollesen, K. (1998). Acanthaceae, pp. 1 - 6. In: S. Cable \& M. Cheek (eds), The Plants of Mount Cameroon. A conservation checklist. Royal Botanic Gardens, Kew.

Vollesen, K. \& Darbyshire, I. (2004). Acanthaceae, pp. 221 - 231. In: M. Cheek, B. J. Pollard, I. Darbyshire, J.-M. Onana \& C. Wild (eds), The plants of Kupe, Mwanenguba and the Bakossi Mountains, Cameroon. A conservation checklist. Royal Botanic Gardens, Kew. 